\title{
PEMANFAATAN DAGING TRIMMED DAN BELLY IKAN TODAK (Tylosurus crocodilus) PADA PEMBUATAN ABON IKAN
}

\author{
Tioko Arzeti Sinambela, R. Marwita Sari Putri ${ }^{*}$, dan Azwin Apriandi \\ Jurusan Teknologi Hasil Perikanan, Fakultas Ilmu Kelautan dan Perikanan, \\ Universitas Maritim Raja Ali Haji, Tanjungpinang \\ *2012wita@gmail.com
}

\begin{abstract}
Abstrak
Abon merupakan salah satu produk berbasis tradisional yang populer di kalangan masyarakat Indonesia. Abon ikan adalah ikan olahan yang dibuat dari daging ikan dan diproses secara tradisional melalui perebusan, pemberian bumbu dan penggorengan / penyangraian. Penelitian ini bertujuan untuk menghasilkan formulasi terbaik pada pembuatan abon ikan berbasis daging trimmed dan belly ikan todak, mengetahui tingkat kesukaan produk abon ikan todak. Hasil pengujian organoleptik yang terbaik adalah formulasi A4 dengan konsentrasi 35\% belly dan $15 \%$ trimmed memberikan nilai rata - rata kenampakan $(3,40)$ aroma $(3,43)$ rasa $(3,27)$ tekstur $(3,5)$. Hasil analisa proksimat berdasarkan perlakuan terbaik didapatkan nilai kadar air $(15,27)$, kadar abu $(8,16)$, kadar lemak $(19,34)$, dan kadar protein $(32,28)$. Hasil pengujian asam amino esensial tertinggi yaitu didapatkan nilai lisin $(2,68 \pm 0,007)$ sedangkan hasil analisa asam amino non esensial tertinngi yaitu didapatkan nilai asam glutamat $(4,84 \pm 0,028)$. Hasil analisa kadar logam $\mathrm{Pb}$ dan $\mathrm{Hg}$ abon ikan dengan nilai rata-rata yaitu $(0,1 \mathrm{mg} / \mathrm{kg})$ dan hasil analisa $\mathrm{Hg}$ dengan nilai rata-rata yaitu $(0,18 \mathrm{mg} / \mathrm{kg})$.
\end{abstract}

Kata Kunci : abon, belly, trimmed, ikan todak, fish floss

\section{PENDAHULUAN}

Berdasarkan SNI 01-3707-1995, abon merupakan hasil pengolahan yang berupa pengeringan bahan baku yang telah ditambahkan bumbu-bumbu untuk meningkatkan cita rasa dan memperpanjang daya simpan.

Jenis ikan yang dibuat sebagai bahan baku jenis abon belum selektif, bahkan hampir semua jenis ikan dapat dijadikan abon, salah satunya ikan todak. Ikan Todak merupakan salah satu ikan yang bernilai ekonomis rendah, di Kota Tanjungpinang sendiri harga ikan ini berkisar antara $\mathrm{Rp} 15.000,00-\mathrm{Rp}$ $20.000,00$ saja. Sejauh ini pengolahan ikan todak biasanya diolah menjadi kerupuk, ikan asin, dan bakso, ikan todak yang ukurannya besar biasanya dimasak gulai, digoreng, dan dibalado, (Dhuhani, 2018).

Pembuatan abon dengan pemisahan antara daging trimmed dan belly didasari atas adanya perbedaan kandungan lemak diantara kedua jenis daging tersebut diberbagai jenis ikan. Berdasarkan penelitian, Hastarini et al. (2012), pada ikan patin Siam dan ikan patin Jambal didapati kandungan lemak 
daging belly sebesar $36,21 \%$ pada ikan patin siam dan $36,50 \%$ pada ikan patin jambal sedangkan lemak daging trimming sebesar $6,63 \%$ pada ikan patin siam dan $10,75 \%$ pada ikan patin jambal. Perbedaan kandungan lemak diantara kedua jenis daging tersebut dirasa cukup untuk menjadi acuan pemisahan antara daging trimmed dan daging belly mengingat salah satu fungsi lemak adalah menambah kalori serta memperbaiki tekstur dan citarasa bahan pangan, (Hermanto et al. 2010).

Daging trimmed dan belly merupakan dua jenis daging yang dipisah perlakuannya. Trimmed merupakan daging hasil proses trimming, proses trimming terdiri dari cabut duri dan penghilangan daging gelap dan belly (daging yang lebih pada bagian bawah perut ikan). Dalam konteks pembuatan abon ini, trimming merupakan pemisahan antara daging dari tulang dan daging bagian jeroan ikan (belly) sehingga menghasilkan daging trimmed sedangkan daging belly merupakan daging bagian perut yang menutupi jeroan pada ikan.

\section{Formulasi Pembuatan Abon}

Tabel 1. Formulasi Abon Trimmed dan Belly Ikan Todak

\begin{tabular}{lccccc}
\hline \multirow{2}{*}{ Bahan } & \multicolumn{5}{c}{ Perlakuan } \\
\cline { 2 - 6 } & $\mathbf{A}_{\mathbf{1}}(\boldsymbol{\%})$ & $\mathbf{A}_{\mathbf{2}}(\boldsymbol{\%})$ & $\mathbf{A}_{\mathbf{3}}(\boldsymbol{\%})$ & $\mathbf{A}_{\mathbf{4}}(\boldsymbol{\%})$ & $\mathbf{A}_{\mathbf{5}}(\boldsymbol{\%})$ \\
\hline Belly & 0 & 15 & 25 & 35 & 50 \\
Trimmed & 50 & 35 & 25 & 15 & 0
\end{tabular}

\section{Pembuatan Abon}

Sebelum diproduksi ikan todak dicuci hingga bersih terlebih dahulu, dengan membuang jeroan lalu dicuci kemudian dilakukan pemisahan antara daging trimmed dan belly, selanjutnya perebusan daging ikan selama 15 menit lalu ikan diangkat kemudian di pressing, setelah itu daging ikan todak ditimbang

\section{METODOLOGI}

\section{Bahan dan Alat}

Alat-alat yang digunakan dalam proses pembuatan abon ini adalah pisau, kompor, dandang, wajan, blender, timbangan digital, dan baskom.

Bahan-bahan yang digunakan dalam penelitian ini terdiri dari bahan utama dan bahan tambahan serta beberapa bahan kimia untuk analisis. Bahan utama yang digunakan adalah daging ikan todak (T. crocodilus). Sedangkan bahan tambahan yang digunakan adalah bawang merah, bawang putih, ketumbar, garam, gula pasir, gula merah, lengkuas, santan dan minyak goreng.

\section{Metode Penelitian}

Penelitian ini dilakukan dalam beberapa tahap yaitu persiapan bahan baku abon, penentuan formualasi abon, persiapan bumbu abon, uji organoleptik mengguakan uji mutu hedonik, pegujian proksimat meliputi kadar air, abu, lemak, dan protein, pengujian asam amino 15 , pengujian cemaran logam $\mathrm{Pb}$ dan $\mathrm{Hg}$, dan analisis data. 
pembuatan abon dapat dilihat pada Gambar 2.

\section{Parameter Pengujian}

Parameter uji yang dilakukan pada penelitian ini meliputi uji uji mutu hedonik, pegujian proksimat meliputi kadar air, abu, lemak, dan protein, pengujian asam amino 15, pengujian cemaran logam $\mathrm{Pb}$ dan $\mathrm{Hg}$, dan analisis data.

\section{Uji Mutu Hedonik}

Pengujian mutu hedonik berperan penting dalam pengembangan produk dengan meminimalkan resiko dalam pengambilan keputusan. Panelis dapat mengidentifikasi sifat-sifat sensori yang akan membantu untuk mendeskripsikan produk. Evaluasi sensori dapat digunakan untuk menilai adanya perubahan yang dikehendaki atau tidak dikehendaki dalam produk atau bahanbahan formulasi, mengidentifikasi area untuk pengembangan, menentukan apakah optimasi telah diperoleh, mengevaluasi produk pesaing, mengamati perubahan yang terjadi selama proses atau penyimpanan, dan memberikan data yang diperlukan bagi promosi produk.

\section{Analisis Proksimat}

\section{a. Kadar Air (SNI 01-2354.2-2006)}

Pengujian kadar air menggunakan wadah cawan porselin kosong yang sudah dipanaskan dalam oven pada suhu $105{ }^{\circ} \mathrm{C}$ sedikitnya 2 jam selanjutnya didinginkan dalam desikator, kemudian ditimbang beratnya sampai berat konstan. Timbang masing-masing 2 gram sampel, selanjutnya cawan yang telah berisi sampel dimasukkan kedalam oven bersuhu $105{ }^{\circ} \mathrm{C}$ sampai beratnya konstan. Pengujian dilakukan sebanyak dua kali ulangan. Persentase kadar air dapat dihitung dengan rumus sebagai berikut :

$$
\text { Kadar air }(\%)=\frac{((\mathrm{A}+\mathrm{B})-\mathrm{C})}{\mathrm{B}} 100 \%
$$

Keterangan :

$\mathrm{A}=$ Bobot wadah kosong $(\mathrm{g})$

$\mathrm{B}=$ Bobot sampel $(\mathrm{g})$

$\mathrm{C}=$ Bobot tetap wadah + sampel setelah pemanasan $(\mathrm{g})$.

\section{b. Kadar Abu (SNI 01-2354.1-2006)}

Pengujian dilakukan dengan memasukkan 2 gram sampel yang telah dihomogenkan kedalam cawan abu porselin kemudian dimasukkan ke dalam oven pada suhu $100{ }^{\circ} \mathrm{C}$ selama 2 jam. Cawan abu porselin kemudian dipindahkan ke dalam tungku pengabuan dan naikkan temperatur secara bertahap sampai mencapai kurang lebih $550{ }^{\circ} \mathrm{C}$.

Pengujian dilakukan sebanyak tiga kali ulangan. Perhitungan kadar abu adalah sebagai berikut :

$$
\text { Kadar abu }(\%)=\frac{(\mathrm{C}-\mathrm{A})}{\mathrm{B}} 100 \%
$$

Keterangan :

$\mathrm{A}=$ Bobot cawan kosong $(\mathrm{g})$

$\mathrm{B}=$ Bobot sampel $(\mathrm{g})$

$\mathrm{C}=$ Bobot tetap cawan + sampel setelah pemijaran $(\mathrm{g})$

\section{c. Kadar Lemak (SNI 01-2354.3-2006)}

Pengujian kadar lemak dengan ditimbang labu alas bulat kosong, lalu masukkan sampel sebanyak 2 gram masukkan ke dalam extractor soxhlet, destruksi pada suhu $60^{\circ} \mathrm{C}$ selama 8 jam. Evaporasi campuran lemak dan chloroform dalam abu alas sampai kering. Masukkan labu alas bulat yang berisi lemak ke dalam oven dengan suhu $105^{\circ} \mathrm{C}$ selama 2 jam untuk menghilangkan sisa chloroform dan uap air. 
Dinginkan labu dan lemak di dalam desikator selama 30 menit. Pengujian dilakukan sebanyak tiga kali ulangan.

Kadar lemak dapat dihitung dengan menggunakan rumus sebagai berikut :

$$
\text { Kadar lemak }(\%)=\frac{(C-A)}{B} 100 \%
$$

Keterangan :

$\mathrm{A}=$ Bobot labu lemak kosong $(\mathrm{g})$

$\mathrm{B}=$ Bobot sampel $(\mathrm{g})$

$\mathrm{C}=$ Bobot tetap labu lemak + sampel setelah pemanasan $(\mathrm{g})$

\section{d. Kadar Protein (SNI 01-2354.4-2006)}

Sampel sebanyak 2 gram dimasukkan kedalam labu kjeldahl 100 ml, kemudian ditambahkan $15 \mathrm{ml} \mathrm{H}_{2} \mathrm{SO}_{4}$ lalu ditambahkan 2 tablet kjeltahl atau katalis $\left(\mathrm{K}_{2} \mathrm{SO}_{4}: \mathrm{CuSO}_{4}=4: 1\right)$ kedalam labu kjeldahl. Labu kjeldahl yang telah berisi larutan dipanaskan sampai cairan berwarna bening. Sampel kemudian didinginkan dan ditambah akuadest $5 \mathrm{ml}$ dan dipindahkan kedalam labu labu destilasi, lalu dibilas lagi dengan aquadest 5-10 $\mathrm{ml}$, kemudian ditambahkan larutan $\mathrm{NaOH} \quad(60$ gr $\mathrm{NaOH}+5$ gr $\mathrm{Na}_{2} \mathrm{~S}_{2} \mathrm{OX}_{3} .5 \mathrm{H}_{2} \mathrm{O}$ dalam $100 \mathrm{ml}$ aquadest) 10-12 ml ke dalam tabung destilasi sampai larutan berwarna coklat kehitaman dan kemudian didestilasi. Hasil destilasi ditampung dengan menggunakan gelas Erlenmeyer $125 \mathrm{ml}$ yang telah berisi $10 \mathrm{ml}$ larutan $\mathrm{H}_{3} \mathrm{BO}_{3} \quad 3 \%$ dan 2-3 tetes indikator campuran metil merah dan metil biru sampai larutan berwarna merah muda.

Hasil dari destilasi ini dititrasi dengan larutan $\mathrm{HCl} 0,02 \mathrm{~N}$ dengan prosedur yang sama dikerjakan juga blanko. Kadar protein dapat dihitung dengan menggunakan rumus sebagai berikut :

$$
\text { Kadar protein }(\%)=\frac{(V p-V b) \times N p \times 1,4007 \times f k}{\text { Gram sampel }} 100 \%
$$

Keterangan :

$V p=$ Volume penitar

$V b=$ Volume blanko

$N p=$ Normalitas penitar

$\mathrm{Fp}=$ Faktor pengenceran

$\mathrm{Fk}=$ Faktor koreksi

\section{Analisis Asam Amino (UPLC)}

Asam amino merupakan komponen penyusun protein. Asam amino esensial adalah asam amino yang tidak dapat dibuat dalam tubuh dan harus diperoleh dari makanan sumber protein yang disebut juga asam amino eksogen. Analisis Komposisi Asam Amino (SIG 2013) Pengujian asam amino dengan metode Ultra Performance Liquid Chromatography (UPLC).

Sampel ditimbang sebanyak $0.1 \mathrm{~g}$ dihancurkan dan dimasukan ke tabung reaksi bertutup. Larutan sampel ditambah $\mathrm{HCl} 6 \mathrm{~N}$ sebanyak 5-10 mL, dihidrolisis dalam oven pada suhu $110^{\circ} \mathrm{C}$ selama 22 jam, lalu di dinginkan pada suhu kamar dan dipindahkan ke labu takar $500 \mathrm{~mL}$. kemudian ditambahkan aquabides hingga tanda batas dan disaring dengan filter $0,45 \mu \mathrm{L}$ dan dipipet $10 \mu \mathrm{L}$, tambahkan $70 \mu \mathrm{L}$ AccQ Fluor Borat dan divortex. Kemudian ditambahkan $20 \mu \mathrm{L}$ reagen Flour Adan divortek dan diamkan selama 1 menit dan di ingkubasi selama 10 menit pada suhu $55^{\circ} \mathrm{C}$. kemudian disuntik pada UPLC sebanyak $1 \mu \mathrm{L}$ dengan kondisi kromotografi menggunakan kolom ACCQ-Tag Ultra C18, temperatur $49^{\circ} \mathrm{C}$, fase gerak sistem komposisi gradient detektorm PDA, laju alir $0,7 \mu \mathrm{L} /$ menit dan panjang gelombang $260 \mathrm{~nm}$. 
Kandungan asam amino dalam bahan dapat dihitung dengan rumus:

Asam A. $(\%)=\frac{\text { kadar asam amino }(\mathrm{mg} / \mathrm{kg})}{10000}$

\section{Analisis Cemaran Logam (ICP- MS)}

ICP-MS (Inductively Coupled Plasma Mass Spectrometry), yaitu pengukuran unsur berdasarkan nomor massa dan mempunyai limit deteksi rendah, penggunaan teknologi ini semakin populer untuk mengukur unsur radioaktif (radionuklida) berkonsentrasi rendah atau bahkan sangat rendah.

Sampel abon ikan ditimbang sebanyak 0,5 - 1,0 gram ke dalam vessel, tambhkan $10 \mathrm{~mL} \mathrm{HNO}_{3}$ pekat (khusus analit $\mathrm{Sn}$ tambahkan 2,5 mL $\mathrm{HNO}_{3}$ pekat dan 7,5 mL HCL pekat). Lalu tutup vessel dan masukkan ke dalam microwave (Ramp ke suhu $150^{\circ} \mathrm{C}$ selama 10 menit, Hold pada suhu $150^{\circ} \mathrm{C}$ selama 15 menit). Panaskan hasil destruksi ke dalam labu ukur $50 \mathrm{~mL}$. Tambahkan secara terukur $0,50 \mathrm{~mL}$ internal standar natrium $100 \mathrm{mg} / \mathrm{L}$ lalu encerkan dengan aquabides higga tanda tera dan homgenkan kemudian saring laruta dengan kertas saring lalu ukur larutan sampel dalam sistem ICP MS.

Parameter yang diperiksa dalam penelitian ini adalah analisis kadar logam berat timbal $(\mathrm{Pb})$, dan merkuri $(\mathrm{Hg})$. Analisis kadar logam berat pada sampel bahan makanan dilakukan dengan dua kali pengulangan.

$$
\text { Kadar logam }=\frac{\mathrm{C} \text { x Vol x Fp }}{\text { Bobot sampel }}
$$

Keterangan :

$\mathrm{C}=$ Larutan

Vol = Volume

$\mathrm{Fp}=$ faktor pengenceran

\section{HASIL DAN PEMBAHASAN}

\section{Uji Mutu Hedonik}

\section{Kenampakan}

Kenampakan atau warna merupakan atribut pertama dilihat oleh konsumen dalam membeli atau mengkonsumsi suatu produk, warna yang menarik akan mengundang selera panelis atau konsumen untuk mencicipi produk tersebut. Kenampakan merupakan salah satu parameter yang menentukan persepsi konsumen terhadap suatu bahan pangan selain cita rasa, tekstur dan nilai gizi. Setelah penampilan atau warna, rasa makanan merupakan faktor kedua yang menentukan cita rasa makanan itu sendiri (Jumiati dan Fadzilla, 2017).

Pada Gambar 1 dapat dilihat bahwa nilai uji mutu hedonik kenampakan tertinggi terdapat pada perlakuan A4 yaitu 3,40. Adapun spesifikasi aroma produk yaitu berwarna coklat keemasan. Hal ini diduga adanya pengaruh penambahan daging belly yang menyebabkan warna abon lebih cerah, sehingga abon tampak lebih menarik. Daging belly berwarna sedikit lebih putih dibandingkan dengan daging trimmed. Selain itu bahan pangan yang disangrai mempunyai permukaan luar berwarna kuning yang disebabkan oleh reaksi maillard, reaksi ini dipengaruhi antara gugus asam amino dari suatu asam amino bebas residu rantai peptida atau protein dengan gugus karboksil dari suatu karbohidrat apabila keduanya dipanaskan, (Lakshmi 2014) Sedangkan reaksi karamelisasi adalah reaksi yang terjadi pada pemanasan gula dalam kondisi asam dan pemanasan tanpa air (Nuraini et al. 2014). 


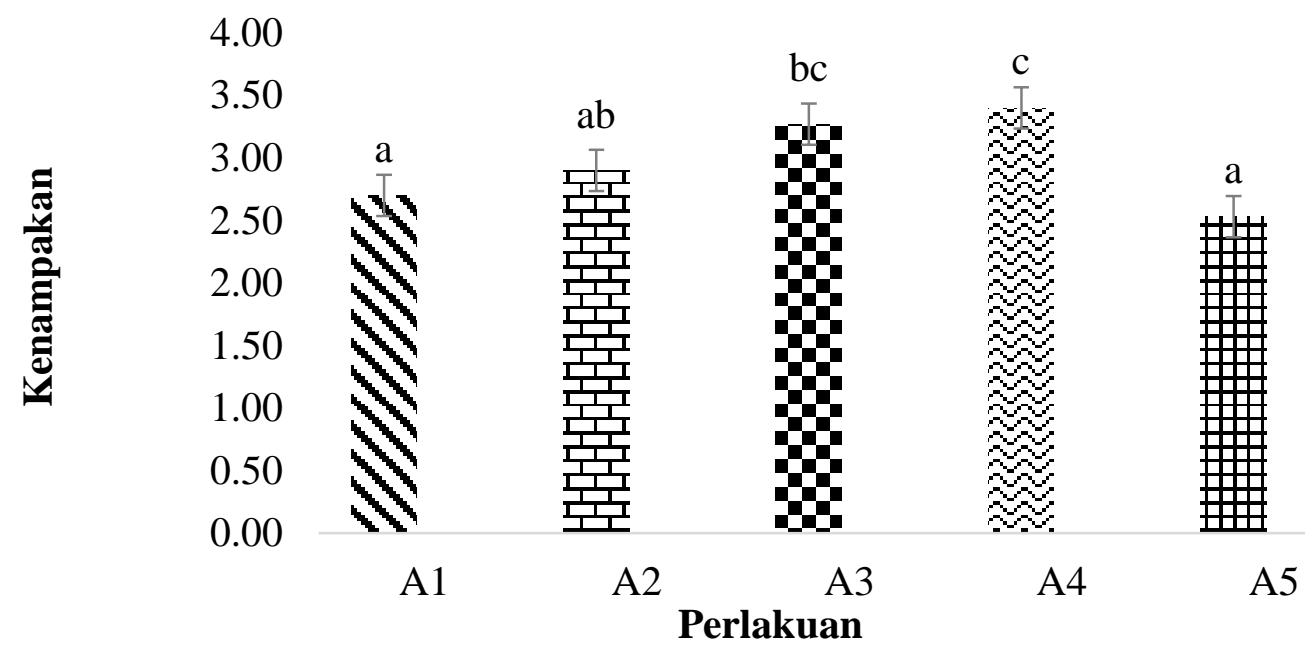

Gambar 1. Histogram Kenampakan Abon Trimmed dan Belly Ikan Todak

Keterangan :

$\mathrm{A}_{1}: 0 \%$ Belly dan 50\% Trimmed $\mathrm{A}_{2}: 15$ Belly dan $35 \%$ Trimmed $\mathrm{A}_{3}: 25 \%$ Belly dan $25 \%$ Trimmed $\mathrm{A}_{4}: 35 \%$ Belly dan $15 \%$ Trimmed $\mathrm{A}_{5}: 50 \%$ Belly dan 0\% Trimmed

\section{Aroma}

Aroma sangat menentukan tingkat penerimaan panelis dari suatu produk karena aroma yang enak atau khas akan meningkatkan selera konsumen, melalui aroma, panelis atau masyarakat dapat mengetahui bahan-bahan yang terkandung dalam suatu produk, (Jusniati et al. 2017).

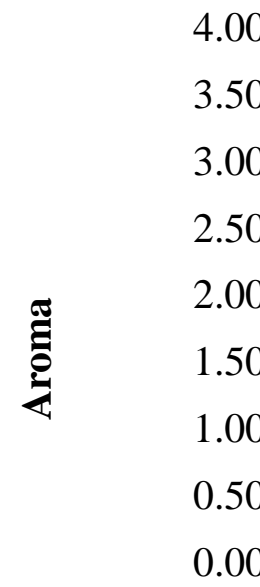

4.00
3.50
3.00
2.50
2.00
1.50
1.00
0.50
0.00
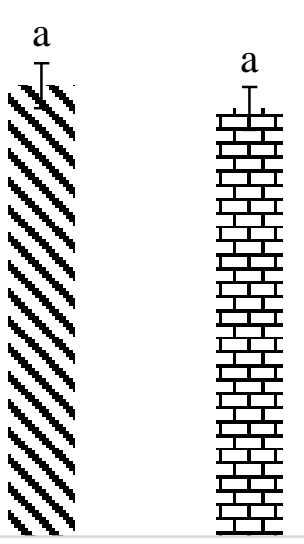

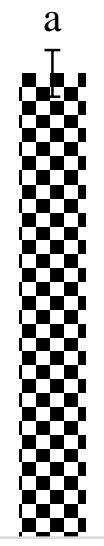

A3

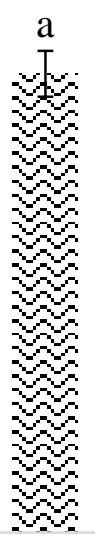

A4

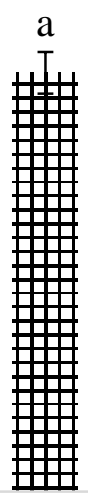

A5

\section{Perlakuan}

Gambar 2. Histogram Aroma Abon Trimmed dan Belly Ikan Todak

Keterangan :

$\mathrm{A}_{1}: 0 \%$ Belly dan 50\% Trimmed

$\mathrm{A}_{2}: 15$ Belly dan $35 \%$ Trimmed

$\mathrm{A}_{3}: 25 \%$ Belly dan $25 \%$ Trimmed
$\mathrm{A}_{4}: 35 \%$ Belly dan $15 \%$ Trimmed

$\mathrm{A}_{5}: 50 \%$ Belly dan 0\% Trimmed 
Pada Gambar 2 dapat dilihat bahwa nilai uji mutu hedonik aroma tertinggi terdapat pada perlakuan A3 yaitu 3,47. Adapun sepefikikasi aroma produk yaitu spesifik abon sangan kuat, artinya ikan dan bumbu-bumbu begitu terasa. Nilai mutu hedonik aroma abon dengan pemisahan antara daging trimmed dan belly tidak memberikan nilai yang jauh berbeda, abon ynag dihasilkan memiliki nilai ynag hampir sama. Hal ini dikarenakan formulasi pembuatan abon masih menggunakan bumbu dengan konsentrasi yang sama, sehingga aroma yang dihasilkan tidak jauh berbeda. Aroma abon ikan dipengaruhi oleh jenis daging, metode pemasakan daging, dan penambahan bumbu-bumbu. Menurut Rohmawati, et al. (2013), bau yang timbul oleh makanan olahan dipengaruhi oleh kombinasi lemak, asam amino dan kadar air, gula, serta suhu pemanasan.

\section{Rasa}

Cita rasa makanan merupakan salah satu faktor penentu bahan makanan, makanan yang memiliki rasa yang enak dan menarik akan disukai oleh konsumen, (Winarno, 2008). Menurut Asiah et al. (2017), cita rasa merupakan gabungan dari aroma dan rasa.

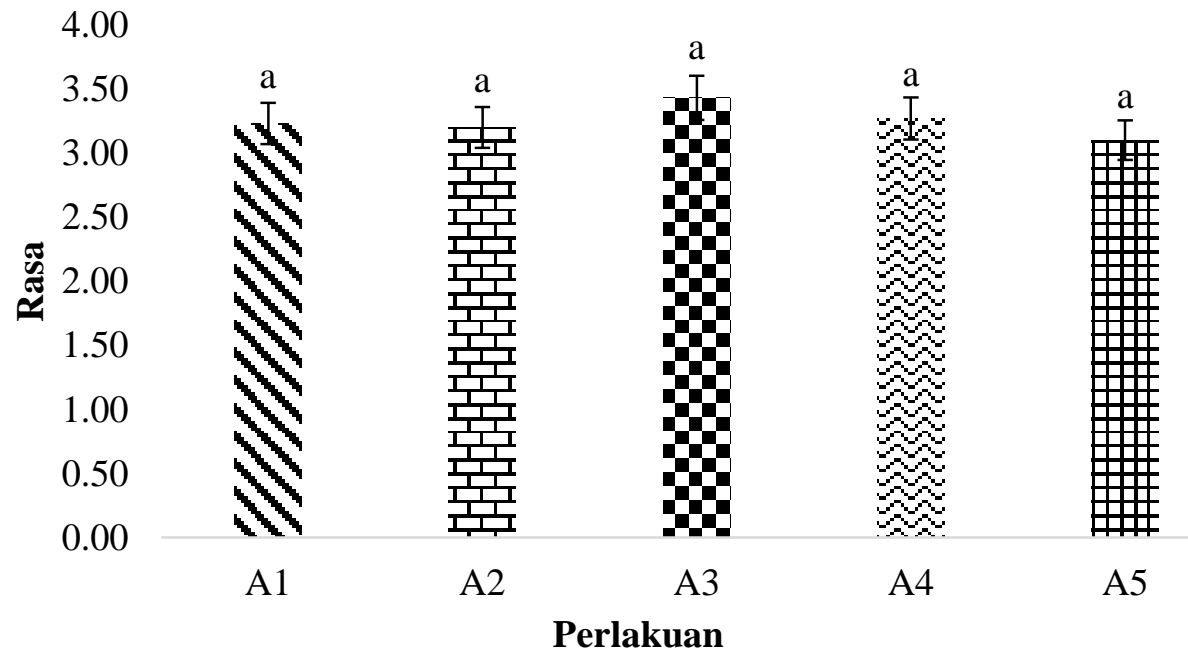

Gambar 3. Histogram Rasa Abon Trimmed dan Belly Ikan Todak

Keterangan :

$\mathrm{A}_{1}: 0 \%$ Belly dan 50\% Trimmed

$\mathrm{A}_{2}: 15$ Belly dan $35 \%$ Trimmed

$\mathrm{A}_{3}: 25 \%$ Belly dan $25 \%$ Trimmed

$\mathrm{A}_{4}: 35 \%$ Belly dan $15 \%$ Trimmed

$\mathrm{A}_{5}: 50 \%$ Belly dan 0\% Trimmed

Pada Gambar 3 dapat dilihat bahwa nilai uji mutu hedonik rasa tertinggi terdapat pada perlakuan $\mathrm{A}_{3}$ yaitu 3,43. Adapun spesifikasi rasa produk yaitu memiliki rasa manis dan cukup gurih. Nilai mutu hedonik rasa abon dengan pemisahan antara daging trimmed dan belly tidak memberikan nilai yang jauh berbeda, abon ynag dihasilkan memiliki nilai ynag hampir sama. Hal ini dikarenakan formulasi pembuatan abon masih menggunakan bumbu dengan konsentrasi yang sama, sehingga rasa yang dihasilkan tidak jauh berbeda. Rasa gurih pada abon ikan dipengaruhi oleh bahan baku dan juga bahan tambahan yang digunakan seperti 
santan, sedangkan rasa manis disebabkan adanya penambahan gula pasir dan gula merah. Hal ini sesuai dengan pernyataan Rohmawati et al. (2013), rasa suatu bahan makanan dapat berasal dari rasa bahan baku itu sendiri dan apabila telah mendapatkan perlakuan pengolahan, maka rasanya dapat dipengaruhi oleh bahan-bahan yang ditambahkan selama proses pengolahan, misalnya bumbubumbu atau flavoring agent. Menurut Muflih et al. (2017), rasa dan aroma memiliki kaitan yang erat, hal ini bisa disebabkan oleh komponen odor yang dihasilkan akibat pemanasan sama.

\section{Tekstur}

Pengamatan tekstur pada produk abon sangatlah penting, karena tekstur merupakan salah satu hal yang membedakan produk abon dengan produk lainnya yaitu berupa serat-serat yang lembut. Tekstur dari daging sangat mempengaruhi produk akhir abon ikan yang dihasilkan dan menentukan tingkat kesukaan konsumen terhadap produk tersebut. Tekstur pada daging yang disuwir umumnya akan berbentuk seperti serat-serat halus, (Jusniati et al. 2017).

Tekstur merupakan bagian penting dari mutu makanan, kadang-kadang lebih penting daripada aroma, rasa dan warna. Hal ini disebabkan karena tekstur merupakan salah satu hal yang membedakan abon ikan dengan produk perikanan lainnya yaitu berupa seratserat yang lembut, (Sultoniyah et al. 2013).

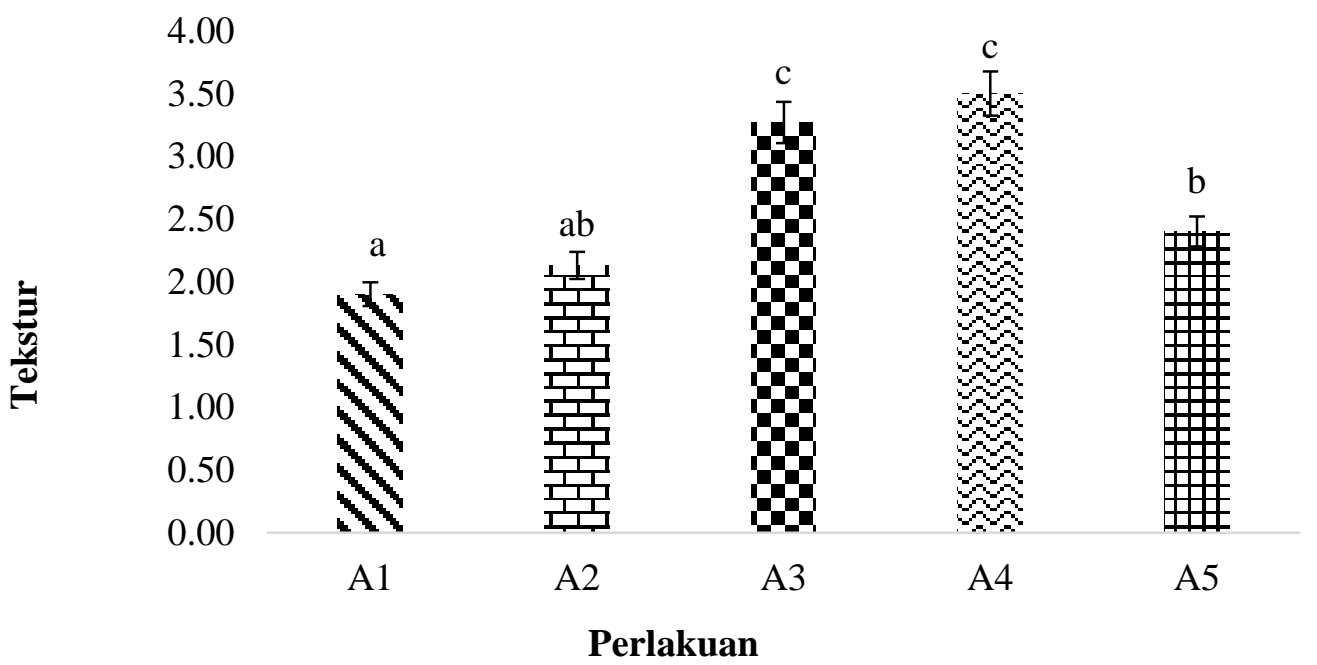

Gambar 4. Histogram Tekstur Abon Trimmed dan Belly Ikan Todak

Keterangan :

A1 : 0\% Belly dan 50\% Trimmed

A2 : 15 Belly dan 35\% Trimmed

A3 : $25 \%$ Belly dan 25\% Trimmed

A4 : $35 \%$ Belly dan 15\% Trimmed

A5 : $50 \%$ Belly dan 0\% Trimmed
Pada Gambar 4 dapat dilihat bahwa nilai uji mutu hedonik tekstur tertinggi terdapat pada perlakuan A4 yaitu 3,5. Adapun spesifikasi tekstur produk abon yaitu memiliki tekstur yang kasar. Hal ini diduga bahwa pada formulasi tersebut abon yang dihasilkan lebih kering dan berserat sehingga 
panelis dapat merasakan tekstur renyah pada saat menelan abon. Tekstur abon juga sangat ditentukan oleh proses penyangraian, pada proses penyangraian kulit terluar dalam bahan akan mengkerut sebagai akibat dari dehidrasi selama proses pengeringan dan akan membentuk pori-pori dibagian dalam bahan pangan sehingga produk memiliki tekstur yang lebih kering (Mustar 2013).

Menurut Mallema (2003) dalam proses pengeringan, semakin banyak pori-pori yang terbentuk dengann pengeluaran uap air dalam bahan pangan maka produk akan semakin kering dan renyah. Selain itu proses pengurangan kadar air akan semakin cepat, selain karena pengaruh panas, tekstur abon juga dipengaruhi oleh dari bentuk daging ikan yang disuwir sehingga permukaan bahan yang lebih luas dan ukuran bahan yang dikeringkan sehingga akan mempermudah proses pengeluaran air dalam bahan dan menjadikan produk memiliki teksur yang lebih kering, (Pakaya et al. 2015).

\section{Analisis Proksimat}

Analisis proksimat pada penelitian ini meliputi kadar air, kadar abu, kadar lemak dan kadar protein.

Tabel 2. Analisis Proksimat Abon Trimmed dan Belly Ikan Todak

\begin{tabular}{lcc}
\hline Parameter & STD Abon & SNI 1995 \\
\hline Kadar air & $15,27 \pm 0,03$ & Maks. 7\% \\
Kadar abu & $8,16 \pm 0,03$ & Maks. 7\% \\
Kadar lemak & $19,34 \pm 0,5$ & Maks. 30\% \\
Kadar protein & $32,28 \pm 0,43$ & Min. 15\% \\
\hline
\end{tabular}

\section{Kadar Air}

Air merupakan komponen yang penting dalam suatu bahan pangan karena air dapat mempengaruhi dari penampakan, tekstur dan cita rasa pada bahan pangan tersebut.

Pada Tabel 2 dapat dilihat bahwa kadar air pada produk abon ikan dengan perlakuan terbaik memberikan nilai ratarata yaitu $15,27 \%$, nilai ini lebih tinggi dari hasil penelitian yang dilakukan, (Aditya et al. 2016) yaitu kadar air pada ikan lampam $\left(\mathrm{A}_{1}\right)$, ikan serandang $\left(\mathrm{A}_{3}\right)$, ikan palau $\left(\mathrm{A}_{4}\right)$, dan ikan motan $\left(\mathrm{A}_{2}\right)$ yang dihasilkan berturut-turut sebanyak $11,89 \%, 6,94 \%, 8,37 \%$, dan $8 \%$. Tingginya kadar air pada abon ikan todak diduga dipengaruhi oleh proses pengolahan yakni tahap penyangraian yang menggunakan suhu rendah kurang dari $90^{\circ} \mathrm{C}$ sehingga menyebabkan kecilnya penguapan. Hal ini sesuai dengan pernyataan Sundari et al. (2015) semakin tinggi suhu yang digunakan semakin rendah kadar airnya.

\section{Kadar Abu}

Kadar abu ini menggambarkan banyaknya mineral yang tidak dapat terbakar menjadi zat yang tidak terbakar menjadi zat yang dapat menguap dan kadar abu juga menentukan ada tidaknya zat mineral dalam suatu bahan pangan.

Pada Tabel 2 dapat dilihat bahwa kadar abu pada produk abon ikan dengan perlakuan terbaik memberikan nilai rata - rata yaitu $8,16 \%$, nilai ini lebih rendah dari hasil penelitian yang dilakukan, Aditya et al. (2016) yaitu kadar abu pada ikan serandang $\left(\mathrm{A}_{3}\right)$, ikan motan $\left(\mathrm{A}_{2}\right)$, 
ikan palau $\left(\mathrm{A}_{4}\right)$ dan ikan lampam $\left(\mathrm{A}_{1}\right)$ yang dihasilkan berturut-turut sebanyak $21,9 \%, 23,09 \%, 23,65 \%$, dan $22,17 \%$. Tingginya kadar abu pada abon ikan terbaik diduga karena banyaknya mineral yang ada pada bahan baku serta pada proses pengolahan abon masih ada duri-duri ikan yang ikut sehingga berpengaruh pada kadar abu. Hal ini sesuai dengan penelitian Putra (2015), semakin rendah tingkat penambahan tulang maka semakin rendah kadar abu kerupuk tulang gabus yang dihasilkan, sebaliknya semakin tinggi tingkat penambahan tulang maka semakin tinggi juga kadar abu kerupuk tulang gabus yang dihasilkan.

\section{Kadar Lemak}

Lemak merupakan zat makanan yang penting untuk kesehatan tubuh manusia. Selain itu lemak juga terdapat pada hampir semua bahan pangan dengan kandungan yang berbeda-beda, (Winarno 2008). Lemak merupakan zat makanan yang penting untuk kesehatan tubuh manusia. Lemak merupakan sumber energi yang lebih efektif dibandingkan dengan karbohidrat dan protein, (Sundari et al. 2015).

Pada Tabel 2 dapat dilihat bahwa kadar lemak pada produk abon ikan dengan perlakuan $\left(\mathrm{A}_{4}\right)$ memberikan nilai rata-rata yaitu $19,34 \%$, hal ini berbeda dengan hasil penelitian yang dilakukan, (Aditya et al. 2016) kadar lemak pada ikan motan $\left(\mathrm{A}_{2}\right)$, ikan serandang $\left(\mathrm{A}_{3}\right)$, ikan palau $\left(\mathrm{A}_{4}\right)$ dan ikan lampam $\left(\mathrm{A}_{1}\right)$ yang dihasilkan berturut-turut sebanyak $17,77 \%, 21,23 \%$, 20,1\%, dan 19,81\%. Tingginya kadar lemak pada abon ikan todak diduga dipengaruhi oleh tingginya kandungan lemak dari bahan baku serta adanya bahan tambahan berupa santan. Hal ini sesui dengan pernyataan, Jumiati et al. (2018), Kandungan lemak lebih tinggi pada abon ikan tongkol dengan bahan tambahan nabati karena dalam proses pembuatan abon ditambahkan santan dan minyak goreng.

\section{Kadar Protein}

Tujuan analisa protein adalah untuk melihat jumlah kandungan protein dalam bahan makanan serta menentukan tingkat kualitas protein dipandang dari sudut gizi.

Pada Tabel 2 dapat dilihat bahwa kadar protein pada produk abon ikan dengan perlakuan $\left(\mathrm{A}_{4}\right)$ memberikan nilai rata-rata yaitu $32,28 \%$, nilai ini lebih tinggi dari hasil penelitian yang dilakukan Aditya et al. (2016) yaitu kadar protein pada ikan serandang $\left(\mathrm{A}_{3}\right)$, ikan palau $\left(\mathrm{A}_{4}\right)$, ikan motan (A2), dan ikan lampam $\left(\mathrm{A}_{1}\right)$ yang dihasilkan berturut-turut sebanyak 16,8\%, 19,21\%, $21,14 \%$, dan $20,71 \%$. Kadar protein di produk pangan dapat di pengaruhi oleh seberapa banyak jumlah konsentrasi daging sebagai bahan baku yang digunakan saat memproduksi produk pangan dan kandungan protein dari bahan tambahan yang digunakan (Putra et al. 2015).

Pada Tabel 3 menunjukkan adanya 8 asam amino esesnsial yang terdapat dalam abon ikan A4 (35\% belly dan 15\% trimmed), yaitu 1-prolin, 1-valin, 1fenilalanin, 1-histidin, isoleusin, 1hreonin, 1-leusin, dan 1-lisn. Sedangkan asam amino nonesensal terdapat 7 jenis yaitu asam 1-tirosin, 1-asam aspartat, asam glutamat, 1-serin, 1-glisin, 1-arginin, dan 1-alanin. Jadi pada abon A4 terdapat 15 jenis asam amino baik yang esensial maunpun asam amino nonesensial. Pada Tabel 5 dapat dilihat bahwa asam amino esensial tertinggi yaitu lisin dengan hasil $2,685 \%$, nilai ini lebih tinggi dari hasil penelitian yang dilakukan oleh Renol et al. (2018) yaitu $2,01 \%$ pada perlakuan L1 (30 menit) menjadi $1,51 \%$ pada perlakuan L4 (45 menit). Sedangkan 
hasil analisa asam amino non esensial tertinngi yaitu asam glutamat dengan hasil $4,841 \%$ nilai ini lebih tinggi dari hasil penelitian yang dilakukan Renol et al. (2018) berturut turut yaitu $(3,92)$,
$(4,00),(4,19)$, dan $(4,65)$. Asam amino esensial terbanyak lainnya terdapat pada asam amino lisin dan asam amino non esensial terbanyak yaitu asam glutamat.

Tabel 3. Kandungan Asam Amino Abon Trimmed dan Belly Ikan Todak

\begin{tabular}{lc}
\hline \multicolumn{1}{c}{ Jenis Asam Amino } & Hasil \% \\
\hline Asam amino esensial & $1,06 \pm 0,007$ \\
L-Prolin & $1,57 \pm 0,007$ \\
L-Valin & $1,01 \pm 0,007$ \\
L-Fenilalanin & $0,69 \pm 0,00$ \\
L-Histidin & $1,41 \pm 0,007$ \\
L-Isoleusin & $1,44 \pm 0,014$ \\
L-Threonin & $2,30 \pm 0,014$ \\
L-Leusin & $2,68 \pm 0,007$ \\
L-Lisin & \\
Asam amino non esensial & $0,67 \pm 0,00$ \\
L-Tirosin & $3,03 \pm 0,014$ \\
L-Asam aspartat & $4,82 \pm 0,028$ \\
L-Asam glutamat & $1,25 \pm 0,007$ \\
L-Serin & $1,43 \pm 0,007$ \\
Glisin & $1,70 \pm 0,007$ \\
L-Arginin & $1,88 \pm 0,007$ \\
L-Alanin & \\
\hline
\end{tabular}

\section{Analisis Cemaran Logam (Pb dan Hg)}

Logam berat merupakan salah satu bahan pencemar perairan, karena keberadaan logam-logam ini sangat berbahaya, meskipun dalam jumlah yang kecil, (Kurniasari et al. 2012).

Tabel 4. Analisis Cemaran Logam Abon Trimmed dan Belly Ikan Todak

\begin{tabular}{lcc}
\hline Cemaran & $\begin{array}{c}\text { Rata }- \text { rata } \\
(\mathbf{m g} / \mathbf{k g})\end{array}$ & $\begin{array}{c}\text { SNI } \\
\text { Abon }\end{array}$ \\
\hline $\mathrm{Pb}$ & 0,18 & Maks 2,0 \\
$\mathrm{Hg}$ & 0,10 & Maks 0,5 \\
\hline
\end{tabular}

Hasil analisa kadar logam Timbal $(\mathrm{Pb})$ pada produk abon ikan dengan perlakuan $\left(\mathrm{A}_{4}\right)$ memberikan nilai ratarata yaitu $0,1 \mathrm{mg} / \mathrm{kg}$ nilai ini lebih rendah dari hasil penelitian yang dilakukan, (Sukesi et al. 2010) Kadar logam $\mathrm{Pb}$ pada abon ikan pari sebesar $0,2773 \mathrm{mg} / \mathrm{kg}$. Sedangkan hasil analisa $\mathrm{Hg}$ pada produk abon ikan dengan perlakuan $\left(\mathrm{A}_{4}\right)$ memberikan nilai ratarata yaitu 0,18 .

Keberadaan logam berat Timbal $(\mathrm{Pb})$ dan Merkuri $(\mathrm{Hg})$ yang menumpuk pada air dan sedimen akan masuk ke dalam kehidupan organisme di dalamnya, logam berat pada konsentrasi tertentu akan terakumulasi ke dalam air, biota, serta sedimen pada perairan tersebut, dan dapat menimbulkan efek toksik terhadap organisme di dalamnya, (Sembel 2015).

Kandungan logam berat pada ikan bersumber dari makanan dan lingkungan perairan yang sudah terkontaminasi oleh logam berat. Kontaminasi makanan dan 
lingkungan perairan tidak terlepas dari aktivitas manusia didarat maupun pada perairan, (Suyanto et al. 2010).

\section{KESIMPULAN DAN SARAN}

Berdasarkan penelitian yang telah dilakukan bahwa formulasi terbaik pada pembuatan abon ikan todak yaitu abon ikan A4 dengan konsentrasi 35\% belly dan $15 \%$ trimmed. Tingkat kesukaan panelis terhadap mutu hedonik kenampakan, aroma, dan tekstur bertutut - turut yaitu $(3,40),(3,43),(3,27)$, dan $(3,50)$. Hasil anaisis proksimat yaitu kadar air dan kadar abu belum memenuhi SNI sedangkan kadar lemak dan kadar protein telah memenuhi SNI. Hasil analisis asam amino esensial tertinggi yaitu lisin dan asam amino non esensial tertinggi yaitu asam glutamat. Hasil analisis cemaran logam timbah $(\mathrm{Pb})$ dan Raksa $(\mathrm{Hg})$ terhadap abon ikan telah memenuhi SNI.

\section{DAFTAR PUSTAKA}

Aditya, H.P., Herpandi., Lesrari, S. 2016. Karakteristik Fisik, Kimia dan Sensoris Abon Ikan dari Berbagai Ikan Ekonomis Rendah. Fishtech - Jurnal Teknologi Hasil Perikanan. 5 (1): 61-72

Asiah, N., Septiyana, F., Saptono, U., Cempaka, L., Sari, D.A. 2017. Identifikasi Cita Rasa Sajian Tubruk Kopi Robusta Cibulao Pada Berbagai Suhu dan Tingkat Kehalusan Penyeduhan. Jurnal Unsika. 2 (2) : 52 - 56.

Dhuhani, A. 2018. Ekoleksikon Perikanan Dalam Bahasa Melayu Kepulauan Riau Desa Tanjung Kelit Kecamatan Senayang Kabupaten Lingga Kepulauan Riau. [Skripsi]. Sastra Indonesia
Fakultas Ilmu Budaya Universitas Sumatera Utara.

Hastarini, E., Fardiaz, D., Irianto, H.E., Budijanto, S. 2012. Karakteristik Minyak Ikan Dari Limbah Pengolahan Fillet Ikan Patin Siam (Pangasius hypopthalmus) dan Patin Jambal (Pangasius djambal). Jurnal Agritech. 32 (4) : 403 - 410. Hermanto, S., Muawanah, A., Wardhani, P. 2010. Analisis Tingkat Kerusakan Lemak Nabati dan Lemak Hewani Akibat Proses Pemanasan.

Jumiati., Fadzilla, F. 2018. Pemanfaatan Jantung Pisang dan Kluwih pada Pembuatan Abon Ikan Tongkol (Euthynnus Affinis) Ditinjau Dari Analisis Proksimat, dan Uji Asam Tiobarbiturat (Tba). Jurnal Reka Pangan. 12 (1). : 60 - 66.

Jusniati., Patang., Kadirman. 2017. Pembuatan Abon dari Jantung Pisang (Musa Paradisiaca) dengan Penambahan Ikan Tongkol (Euthynnus Affinis). Jurnal Pendidikan Teknologi Pertanian. 3: 58-66.

Kurniasari, L., Riwayati, I., Suwardiyono. 2012. Pektin Sebagai Alternatif Bahan Baku Biosorben Logam Berat. Jurnal Unwahas Momentum. 8 (1) : 1- 5.

Lakshmi, C.G. 2014. Food Coloring: The Natural Way. Research Journal of Chemical Sciences. 4(2): 87-96.

Mallema, M. 2003. Mechanism and Reduction of Fat Up Take in Deep Fat Fried Food. Food Sci Journal. 14 : 436-437.

Muflih, A., Yanto, S., Lahming. 2017. Pengaruh Variasi Media Penggorengan terhadap Pengolahan Abon Ikan Betok (Anabes Testidineus). Jurnal Pendidikan Teknologi Pertanian. 3 (4) :52-59. 
Mustar. 2013. Studi pembuatan Abon Ikan Gabus (Ophiocephalus Striatus) sebagai Makanan Suplemen (Food Suplement). Teknologi pertanian Universitas Hasanuddin, Makassar.

Renol., Gobel, G., Nilawaty, J. 2018. Karakterisasi Profil Asam Amino dan Kadar Protein Abon Ikan Tongkol (Euthynnus Affinis) Pada Berbagai Lama Penggorengan. Jurnal Mitra Sains. 6 (1) : 94-100.

Nuraini, A., Ibrahim, R., Rianingsih, L. 2014. Pengaruh Penambahan Konsentrasi Sumber Karbohidrat dari Nasi dan Gula Merah yang Berbeda terhadap Mutu Bekasam Ikan Nila Merah (Oreochromis Niloticus). Jurnal Saintek Perikanan 10 (1) : 19-25.

Pakaya, R., Mandey, L.C., Lumoindong, F. 2015. Pengaruh Penambahan Jantung Pisang Goroho (Musa Sp.) terhadap Kandungan Gizi dan Organoleptik Abon Ikan Cakalang (Katsuwonus Pelamis). Jurnal Ilmu dan Teknologi Pangan. 3 (2): 15-23.

Putra D.A.P., Agustini TW., Wijayanti I. 2015. Pengaruh Penambahan Karagenan sebagai Stabilizer terhadap Karakteristik Otak-Otak Ikan Kurisi (Nemipterus Nematophorus). Jurnal Pengolahan dan Bioteknologi Hasil Perikanan. 4(2): 1-10.

Rohmawati, N., Sulistiyani., Ratnawati, L.Y. 2013. Pengaruh Penambahan Keluwih (Artocarpus Camasi) terhadap Mutu Fisik, Kadar Protein, dan Kadar Air Abon Lele
Dumbo (Clarias Gariepinus). Jurnal Ikesma. 9 (2) : 127 - 135.

Sembel. 2015. Toksikologi Lingkungan Dampak Pencemaran dari Berbagai Bahan Kimia dalam Kehidupan Sehari-hari. Penerbit Andi. Yogyakarta.

Standar Nasional Indonesia. 1992. SNI 01-2891-1992. Penentuan Uji Proksimat pada Makanan dan Minuman.

Standar Nasional Indonesia. 2006. SNI 01-2346-2006. Petunjuk Pengujiaan Organoleptik atau Sensori.

Standar Nasional Indonesia. 1995. SNI 01-3707-1995. Standar Mutu Abon. Jakarta: Badan Standardisasi Nasional.

Sulthoniyah, S. T. M., Sulistiyati, T. D., dan Suprayitno, E. 2012. Pengaruh Suhu Pengukusan terhadap Kandungan Gizi dan Organoleptik Abon Ikan Gabus (Ophiocephalus striatus). THPi Student Journal. 1(1) : 33-45.

Sundari, D., Almasyhuri, Lamid, S. 2015. Pengaruh Proses Pemasakan terhadap Komposisi Zat Gizi Bahan Pangan Sumber Protein. Jurnal Media Litbangkes. 25 (4) : $235-242$.

Suyanto, A., Kusmiyati, S., Retnaningsih, Ch. 2010. Residu Logam Berat Ikan dari Perairan Tercemar di Pantai Utara Jawa Tengah. Jurnal Pangan Dan Gizi. 1 (02).

Winarno, F.G. 2008. Kimia Pangan dan Gizi: Edisi Terbaru. Jakarta. Gramedia Pustaka Utama. 